Asthma is characterized by airway inflammation, which can be now assessed by the analysis of induced sputum. Ten patients with asthma were investigated during acute exacerbation for the quantification of apoptosis, for Bcl-2 and Fas expression, in induced sputum lymphocytes. They were compared to 12 patients with chronic obstructive pulmonary disease (COPD), and 10 healthy controls. Spontaneous apoptosis was determined by staining nuclei with propidium iodide, and analyzed with a FACScan. Bcl-2 was measured by Western blotting, and results were obtained by densitometric scanning, done by the gel proanalyser. The investigation of Fas was performed using the streptavidin-biotin preroxidase-complex method. Patients with asthma and patients with COPD exhibited a significant increase of cellularity, percentage of neutrophils, eosinophils and lymphocytes when compared to healthy controls. Apoptosis in induced sputum mononuclear cells was found decreased in patien ts with asth ma compared to COPD patients and healthy controls. The quantification of apoptosis was measured after exposure to anticytokin e an tibodies. An ti-TNF- $\alpha$ an tibody blocked the apoptosis in both patients groups and healthy controls, suggesting that TNF- $\alpha$ acted as an inducer of apoptosis. Anti-IL-10 blocked apoptosis completely exclusively in patients with asth ma. Bcl-2 expression was found to be increased in induced sputum mononuclear cells from patients with asth $m a$, compared to healthy controls and patients with COPD. Expression of Fas could be detected in patients with asthma, at a lower level than COPD patients and healthy controls. Distinct mechanisms of apoptosis were found in patien ts with asth $m$ a and patien ts with COPD, characterized by different levels of Bcl-2 and Fas expression. Induction of apoptosis should be a beneficial process in allergic inflam mation traduced in induced $s$ putum mononuclear cells. The apoptosis process is assumed by two different mechanisms in asthma and COPD. Our findings indicated that in asthmatic patients, activated lymphocytes accumulate in the bronchi; because of their prolonged survival that maintains in flam $m$ ation.

Key words: Asthma, Chronic Obstructive Pulmonary Disease, Apoptosis, Lymphocytes, Bcl-2, Fas

Key Indexing Term: Apoptosis and related proteins in Asthm a and COPD

\section{Lymphocytes apoptosis in patients with acute exacerbation of asthma}

\author{
Agnès Hamzaoui ${ }^{1}$, Kamel Hamzaoui ${ }^{2}$, Habib Salah ${ }^{1}$ \\ and Abdellatif Chabbou ${ }^{3}$
}

${ }^{1}$ Department of Respiratory Diseases, Pavillon B, Ariana, Tunisia, ${ }^{2}$ Immunohistology Laboratory, Medicine University of Tunis, Pavillon 6, and ${ }^{3}$ Department of Respiratory Diseases, Pavillon 2, Ariana, Tunisia.

${ }^{\mathrm{CA}}$ Corresponding Author

Kamel Hamzaoui, Pr., Medicine University Tunis, 9, Rue du Dr. Z. Essafi 1006 Tunis, Tunisia

Fax: (216) 1569427

Email: Kamel.Hamzaoui@fmt.rnu.tn

\section{Introduction}

Infiltration of the airways mucosa with activated inflammatory cells appears to be a major factor in the pathogenesis of asthma and other forms of chronic obstructive airw ay disorders, such as chronic obstructive pulmonary disease (COPD). The cells and molecular markers of this inflammation have been studied by bronchoalve olar lavage (BAL) and bronchial biopsies but the use of these techniques has been limited in certain patients by their invasiveness. In order to overcome the difficulties associated with bronchoalveolar lavage and the sampling of bronchial biopsies via the bronchoscope, analys is of induced sputum has recently been suggested for repeated evaluation of airway inflammation in patients with asthma. Examination of induced sputum allows investigation the airway inflammation directly without important secondary effects. Inflammatory markers can be studied on cells and supernatants. 
Inflammation plays a key role in the pathophysiology of as thma ${ }^{1}$ and COPD. In bronchial biopsies of patients with asthma, primarily eosinophils, monocytes/macrophages and Tlymphocytes ${ }^{1,2}$ are seen. In lobar bronchial biopsies of subjects with chronic bronchitis, an increased number of leukocytes, both in the epithelium and in the lamina propria, consisting predominantly of macrophages and activated T-cells, was found. Eosino phils are the more prominent cells in asthma, and their activation is supposed to be involved in tissue destruction. Epithelial bronchial cells are now considered essential in modulating bronchial tissues remodeling (subepithelial fibrosis, muscular hyperplasia). However, Tlymphocytes are still essential in asthma inflammation as the $\mathrm{TH} 2$ cytokines are characte ris tic of allergic pathw ays and partic ularly of as thma. Moreover, the major drugs used in asthma (steroids) are powerful immunosuppressors, reflecting importance of the immunologic pathways.

Homeostasis of cell number is achieved by balancing the proliferative and anti-proliferative states of cells. Anti-proliferative states include growth arrest, differentiation, senescence (cellular ageing), and apoptosis. Apoptosis, a dynamic process involved in the control of the 'tissue load' of immune effector cells at inflamed sites, tends to limit inflammatory tissue injury and to promote resolution rather than progression of inflammation. ${ }^{3}$ The inflammatory process could be traduced by certain proto-oncogenes, which regulate the programmed cell death: apoptosis. Fas and the members of the Bcl-2 gene family have emerged as key regulators of the apoptotic process. ${ }^{4}$ In bronchial biopsies, the number of apoptotic eosinophils and macrophages was found to be lower in subjects with asthma than those with COPD and inversely correlated with the clinical severity of asthma, ${ }^{5}$ reflecting longer survival of these cells.

As lymphocytes are involved in the initial events of recruitment and activation of inflammatory cells, we supposed that they have to disappear to allow inflammation resolution. The aim of our study was to investigate bronchial lymphocytes apoptosis in acute asthma exacerbation. The cells were recovered on induced sputum. In this work, we will discuss how the use of sputum, and the analyses of apoptosis, promise to provide new insights into understanding inflammatory airw ay diseases.

\section{Materials and methods}

\section{Patients}

Induced sputum samples were collected from 10 successive patients with asthma, and 12 patients $w$ ith COPD (Table 1). All were inpatients, admitted for an acute wheezing exacerbation of dyspnea, usually by the emergency services. The sample was obtained the day after their admission. A precise history of the patient was subsequently obtained, and after recovery functional respiratory tests and eventually skin tests were realized. The following patients were excluded: concomitant infectious pneumonia, tuberculosis,

Table 1. Clinical manifestations and treatment. A: asthma; B: COPD; PY: pack year; GS: glucosteroids; $y$ : yes; n: negative results; asthma severity: 2: mild, 3: moderate, 4: severe.

\begin{tabular}{|c|c|c|c|c|c|c|c|c|c|c|c|c|c|}
\hline \multirow[t]{3}{*}{ Patients } & \multirow[t]{3}{*}{ Age } & \multirow{3}{*}{$\begin{array}{c}\text { Smoking } \\
\text { PY }\end{array}$} & \multirow[t]{3}{*}{ Atopy } & \multirow{2}{*}{$\begin{array}{l}\text { Reversi- } \\
\text { bility }\end{array}$} & \multirow{3}{*}{$\begin{array}{l}\text { Skin } \\
\text { tests }\end{array}$} & \multirow{2}{*}{\multicolumn{2}{|c|}{$\begin{array}{c}\text { Dyspnea history } \\
\text { (years) }\end{array}$}} & \multirow{3}{*}{$\begin{array}{l}\text { Asthma } \\
\text { severity }\end{array}$} & \multirow{3}{*}{$\begin{array}{l}\text { Productive } \\
\text { cough }\end{array}$} & \multicolumn{3}{|c|}{ Previous treatment } & \multirow{3}{*}{$\begin{array}{c}\text { Previous } \\
\text { hospitalis- } \\
\text { ations } \\
\text { (number) }\end{array}$} \\
\hline & & & & & & & & & & & Theo- & GS & \\
\hline & & & & $\begin{array}{c}\text { Beta } 2 \text { GS } \\
\text { test test }\end{array}$ & & $\begin{array}{c}\text { Acute } \\
\text { dyspnea }\end{array}$ & $\begin{array}{c}\text { Persistant } \\
\text { dyspnea }\end{array}$ & & & agonists & phylline & & \\
\hline
\end{tabular}

\begin{tabular}{|c|c|c|c|c|c|c|c|c|c|c|c|c|c|c|}
\hline A1 & 47 & 30 & $y$ & $p$ & & $p$ & 8 & 0 & 3 & $y$ & $y$ & $y$ & $y$ & 2 \\
\hline $\mathrm{A} 2$ & 22 & 1 & $y$ & $p$ & & $p$ & 3 & 0 & 2 & $\mathrm{n}$ & $\mathrm{n}$ & $n$ & $y$ & 1 \\
\hline A3 & 65 & 40 & $\mathrm{n}$ & $p$ & & $n$ & 8 & 3 & 4 & $\mathrm{n}$ & $y$ & $y$ & $y$ & 4 \\
\hline A4 & 47 & 0 & $y$ & $p$ & & $p$ & 11 & 7 & 4 & $\mathrm{n}$ & $\mathrm{n}$ & $\mathrm{n}$ & $\mathrm{n}$ & 1 \\
\hline A5 & 47 & 0 & $y$ & $p$ & & & 5 & 0 & 2 & $\mathrm{n}$ & $y$ & $y$ & $\mathrm{n}$ & 1 \\
\hline A6 & 80 & 0 & $\mathrm{n}$ & $\mathrm{n}$ & $\mathrm{n}$ & $\mathrm{n}$ & 10 & 0,1 & 3 & $y$ & $\mathrm{n}$ & $y$ & $y$ & 2 \\
\hline A7 & 31 & 0 & $y$ & $\mathrm{n}$ & $p$ & $p$ & 26 & 1 & 4 & $\mathrm{n}$ & $y$ & $y$ & $\mathrm{n}$ & 2 \\
\hline A8 & 30 & 15 & $y$ & $p$ & & $p$ & 12 & 0 & 2 & $\mathrm{n}$ & $y$ & $y$ & $\mathrm{n}$ & 2 \\
\hline A9 & 28 & 0 & $y$ & $n$ & $p$ & $p$ & 6 & 0 & 3 & $y$ & $y$ & $y$ & $y$ & 3 \\
\hline A10 & 46 & 10 & $y$ & $p$ & & $p$ & 29 & 3 & 4 & $y$ & $\mathrm{n}$ & $y$ & $y$ & 2 \\
\hline B1 & 88 & 49 & $\mathrm{n}$ & $\mathrm{n}$ & $\mathrm{n}$ & $p$ & 20 & 9 & & $\mathrm{n}$ & $y$ & $y$ & $\mathrm{n}$ & 1 \\
\hline B2 & 71 & 124 & $\mathrm{n}$ & $\mathrm{n}$ & $\mathrm{n}$ & $\mathrm{n}$ & 0,2 & 0,2 & & $y$ & $\mathrm{n}$ & $\mathrm{n}$ & $\mathrm{n}$ & 1 \\
\hline B3 & 59 & 20 & $\mathrm{n}$ & $\mathrm{n}$ & $\mathrm{n}$ & & 20 & 5 & & $y$ & $y$ & $y$ & $y$ & 3 \\
\hline B4 & 68 & 100 & $\mathrm{n}$ & $\mathrm{n}$ & $\mathrm{n}$ & & 0 & 8 & & $y$ & $\mathrm{n}$ & $\mathrm{n}$ & $\mathrm{n}$ & 1 \\
\hline B5 & 59 & 75 & $\mathrm{n}$ & $\mathrm{n}$ & $\mathrm{n}$ & $p$ & 10 & 1 & & $y$ & $y$ & $y$ & $\mathrm{n}$ & 3 \\
\hline B6 & 65 & 20 & $\mathrm{n}$ & $\mathrm{n}$ & $\mathrm{n}$ & $p$ & 10 & 2 & & $y$ & $y$ & $y$ & $y$ & 1 \\
\hline B7 & 61 & 30 & $y$ & $\mathrm{n}$ & $\mathrm{n}$ & & 13 & 13 & & $y$ & $\mathrm{n}$ & $y$ & $n$ & 1 \\
\hline B8 & 52 & 60 & $\mathrm{n}$ & $\mathrm{n}$ & $\mathrm{n}$ & $\mathrm{n}$ & 15 & 3 & & $\mathrm{n}$ & $\mathrm{n}$ & $\mathrm{n}$ & $y$ & 1 \\
\hline B9 & 82 & 20 & $\mathrm{n}$ & $\mathrm{n}$ & $\mathrm{n}$ & $\mathrm{n}$ & 3 & 0 & & $\mathrm{n}$ & $\mathrm{n}$ & $\mathrm{n}$ & $\mathrm{n}$ & 1 \\
\hline B10 & 64 & 100 & $\mathrm{n}$ & $\mathrm{n}$ & $\mathrm{n}$ & $n$ & 40 & 1 & & $y$ & $y$ & $y$ & $\mathrm{n}$ & 3 \\
\hline B11 & 63 & 69 & $\mathrm{n}$ & $p$ & $p$ & $\mathrm{n}$ & 15 & 0,1 & & $y$ & $\mathrm{n}$ & $\mathrm{n}$ & $\mathrm{n}$ & 1 \\
\hline B12 & 80 & 80 & $\mathrm{n}$ & $p$ & & $n$ & 1 & 0 & & $y$ & $\mathrm{n}$ & $n$ & $\mathrm{n}$ & 1 \\
\hline
\end{tabular}


interstial lung diseases, bronchiectas is, lung cancer, and associated acute pathologies: cardiac, renal, liver, or neurological diseases.

Ten induced sputum from healthy subjects (mean age 28.7 yrs; range 22-36), who had normal pulmonary radiographs and showed no clinical signs of respiratory diseases, acted as controls. Informed consent was obtained from all the patients. The study was approved by the local Ethics Committee.

\section{Sputum induction}

After the inhalation of salbutamol $(2 \times 200 \mu \mathrm{g})$, subjects were asked to inhale sterile, pyrogen-free, hypertonic saline in increasing concentrations for a duration of $10 \mathrm{~min}$. The hypertonic saline was nebulized via an ultrasonic nebulizer. Subjects were encouraged to cough throughout the procedure. Most patients were able to expectorate an adequate sample ( $7 \mathrm{ml}$ and more) within the first $10 \mathrm{~min}$.

\section{Sputum processing}

In order to reduce salivary contamination, plugs were selected and transferred into an Eppendorf tube. Freshly prepared $10 \%$ solution of dithiothreitol $(1 \mathrm{ml})$ (DTT) was added. The tube was vortex mixed and the sputum was incubated for $5 \mathrm{~min}$ at room temperature, filtered through $52 \mu \mathrm{m}$ nylon gauze to remove debris and mucus, and subsequently centrifuged at $450 \times \mathrm{g}$ for $10 \mathrm{~min}$. The cell pellet was resuspended in phosphate-buffered saline (PBS) in a volume equal to the sputum plus DTT solution volume. Total cell counting was carried out in a haemocytometer and the cell concentration was adjusted to $1.0 \times 10^{6}$ cells $/ \mathrm{ml}$. Cytospins were prepared by adding $75 \mu \mathrm{l}$ cell suspension into Shandon II cytocentrifuge cups (Shandon Southern Instruments) and spun for $8 \mathrm{~min}$ at $500 \mathrm{rpm}$. Two slides were stained with Wright-Giemsa for an overall differential cell count of leukocytes, bronchial epithelial cells and squamous cells. Slides were coded and counted blind by two investigators. None of the cytospins containe $d>5 \%$ squamous epithelial cells. For cell differentiation, 400 nucleated cells per slide were counted (Table 2) and expressed as the percentage of intact round nucleated cells, excluding the squamous epithelial cells.

\section{Quantification of apoptosis}

Lymphocytes were isolated by Ficoll-Hypaque (Pharmacia, Uppsala, Sweden) density gradient centrifugation and washed twice with $\mathrm{PBS}$ at $4+^{\circ} \mathrm{C}$, as we have recently reported. ${ }^{5}$ Cell pellet expressed more than $80 \%$ CD3-positive cells as determined by anti-CD3 monoclonal antibody (Becton Dickinson). These T-cells were double labeled with anti-CD3 and
Table 2. Subjects' cell characteristics.

\begin{tabular}{lccc}
\hline Cells & Asthma & BPCO & $\begin{array}{c}\text { Healthy } \\
\text { controls }\end{array}$ \\
\hline $\begin{array}{l}\text { Number of } \\
\text { cells } \times 10^{6}\end{array}$ & 2.5 & 1.9 & 1.4 \\
Viability \% & $84-2,7)$ & $(0,9-2,1)$ & $(0.8-1.8)$ \\
& $(45.5-94.5)$ & $(56.5-92.7)$ & $(75.6-92.0)$ \\
\% macrophages & 52.56 & 49.63 & 42.8 \\
& $(40.3-62.9)$ & $(40.4-59.3)$ & $(22.7-65.0)$ \\
\% neutrophils & 32.85 & 35.49 & 28.0 \\
& $(25.2-50.5)$ & $(24.8-46.5)$ & $(19.8-41.4)$ \\
\% eosinophils & 5.7 & 4.79 & 1.7 \\
& $(2.7-9.5)$ & $(1.6-8.1)$ & $(0.6-2.9)$ \\
\% lymphocytes & 7.45 & 8.73 & 3.9 \\
& $(4.2-12)$ & $(3.0-14.5)$ & $(0.5-4.3)$ \\
\% epithelial cells & 1.1 & 0.9 & 1.6 \\
& $(0.2-5.6)$ & $(0.4-2.3)$ & $(1,4-6,7)$ \\
\hline
\end{tabular}

anti-CD25 monoclonal antibodies in original (Becton Dickinson).

Apoptosis was quantified on lymphocytes by staining nuclei with propidium iodide (PI) and analysing fluorescence with a FACScan (Becton Dickinson. Mountain View, CA). Briefly following culture for $18 \mathrm{~h}$, lymphocytes were collected after centrifugation with RPMI 1640 at $150 \mathrm{~g}$ for $10 \mathrm{~min}$. The pellet was washed twice in complete medium (RPMI 1640 supplemented with $2 \mathrm{mM}$ L-glutamine, $100 \mathrm{U} / \mathrm{ml}$ benzyl-penicillin, $100 \mu \mathrm{g} / \mathrm{ml}$ streptomycin and containing $10 \%$ fetal calf serum). The pellet collected from induced sputum was gently suspended in $0.5 \mathrm{ml}$ of hypotonic fluochrome solution $(0.1 \%$ sodium citrate with $0.1 \%$ Triton X-100) containing $20 \mathrm{mg}$ per $\mu \mathrm{l}$ PI for $2 \mathrm{Omin}$. RNAse A at a concentration of $10 \mathrm{mg} / \mathrm{ml}$ was added and cells were further incubated for $10 \mathrm{~min}$ at $4^{\circ} \mathrm{C}$. The suspension was analyzed by flow cytometry to determine PI fluorescence of individual nuclei. Apoptotic nuclei appeared as a broad hypodiploïd DNA peak that was easily discriminated from the narrow peak of nuclei with normal (diploid) DNA content. Student's $t$-test was used for statistical analys is of data and $p<0.01$ was taken as significant.

\section{Detection of Fas by immunochemistry}

For measuring the expression of the Fas-antigen, induced sputum cytospins were fixed with ice-cold acetone for $10 \mathrm{~min}$. Immunocytochemical investigation of Fas was performed using the streptavidin-biotin preroxidase-complex method. Cell preparations were pre-incubated with hydrogen peroxide $(0.3 \%, 15 \mathrm{~min})$, unlabeled streptavidin (dilution 1:50,15 min) and nonimmune normal sheep serum. After each step slides were washed three times in PBS. The Fas-antibody antibody (Immunotech, France) was used in a dilution 
as indicated by the manufacture $r$ and applied overnight at $4^{\circ} \mathrm{C}$. After three washes in PBS the cells were incubated for $45 \mathrm{~min}$ with biotinylated sheep antimouse IgG (Amersham; diluted 1:50 w ith 5\% normal serum). After washing three times with PBS, the streptavidin-biotinylated peroxidase complex (Amersham, 1:100, $30 \mathrm{~min}$ ) was added and subsequently washed $w$ ith PBS (three times). Peroxidase activity was made visible with 3 -amino 9-ethycarbazole $(20 \mathrm{~min})$, which gives a red-brown reacting product. Counterstaining was performed with haematoxylin and sections were mounted with glycerol gelatine. Negative controls were obtained, firstly, omitting the primary antibodies and secondly, by an irrelevant antibody. For Fas-antigen, the percentage of stained cells was estimated for each slide and the samples were classified as cells with low Fas expression if less than $1.5 \%$ (mean value) stained cells were present and as high Fas-expression samples if $1.5 \%$ or more of the cells were stained.

\section{Expression of $\mathrm{Bcl}-2$ by western blotting}

The expression of Bcl-2 in induced sputum lymphocytes was determined by Western blotting. Equal amounts of protein were loaded on SDS-PAGE and blotted onto nitrocellulose paper. The Bcl-2 protein was detected by rabbit anti-human Bcl-2 antibody (Santa Cruz Biotechnology, CA) and anti-rabbit peroxidase conjugate as secondary antibody with diaminobenzidine as substrate. Densitometric scanning of the blot was done by the gel proanalyser from Media Cybernetics.

\section{Statistical analysis}

Values are presented as mean value (SEM). Differences between groups are analyzed using the MannWhitney U-test. Probability values of $p<0.05$ were considered significant. Reproducibility of sputum cell counts was examined by repeated-measures. Values $>0.70$ indic ate high reliability.

\section{Results}

\section{Patients}

According to clinical history, functional (spirometry, and reversibility with beta 2 agonists or steroids) and skin tests results, patients were classified as asthmatic patients or COPD. Chronic asthma severity was classifie $\mathrm{d}$ according to GINA re commendations. ${ }^{6}$ Three patients were difficult to diagnose definitely as asthma or COPD (A1, B11 and B12) but we decided not to exclude them, the results obtained on their samples reflecting a real association of the 2 diagnosis.

\section{Differential cell counts}

Differential cell count in induced sputum was reported in Table 2. Patients with COPD and patients with asthma exhibited a higher total cell number, an increased percentage of macrophages, eosinophils and neutrophils when compared to healthy control induced sputum $(p<0.01)$. Patients with asthma and patients with COPD exhibited significant increased levels of lymphocytes when compared to healthy controls $(p<0.01)$.

\section{Quantification of apoptosis}

Induced sputum lymphocytes from patients with asthma, patients with COPD and healthy controls, showed spontaneous apoptosis (mean \pm s.e.m.) after $18 \mathrm{~h}$ of culture of lymphocytes in the absence of mitogens (Figure 1). These lymphocytes were CD3and $\mathrm{CD} 25$-positive. The percentage of apoptosis was significantly decreased in patients with asthma $(11.37 \% \pm 5.31 \% ; p<0.01)$ compared with COPD patients $(14.82 \% \pm 4.46 \%)$, and healthy controls $(26.09 \% \pm 12.34 \%)$.

Pathogenic concepts of allergic diseases include a central role for differential cytokine production, characterized as Th0/Th2 profile. Then we tested if certain anti-cytokines antibodies could block the apoptosis in patients with asthma, with COPD and in healthy controls.

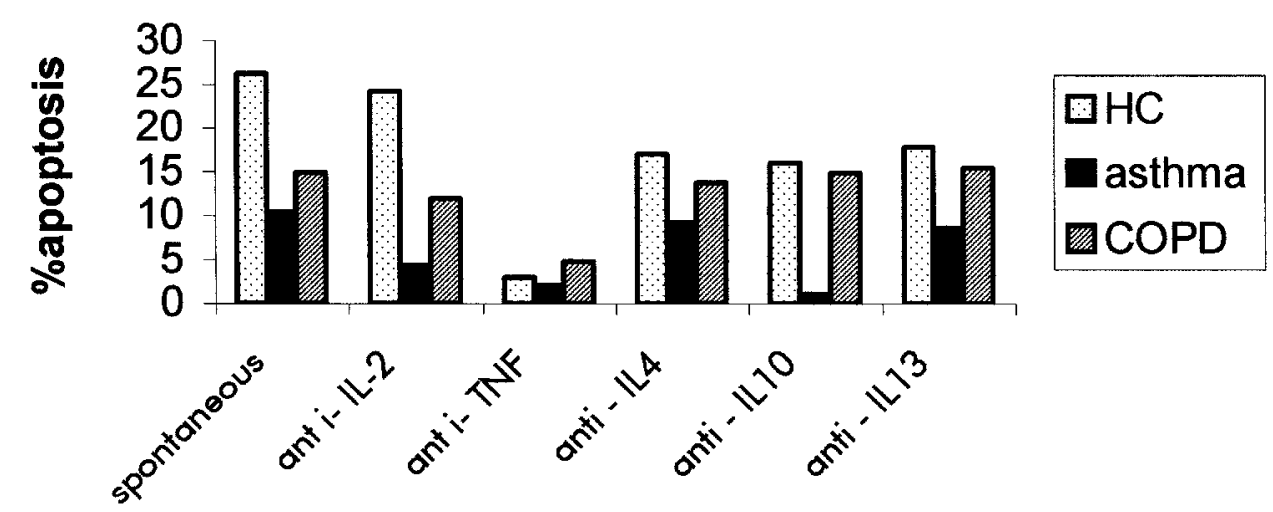

FIG. 1. Percentage of apoptosis in patients with asthma $(n=10)$, in patients with COPD $(n=12)$, and in healthy controls (HC) $(n=10)$. 


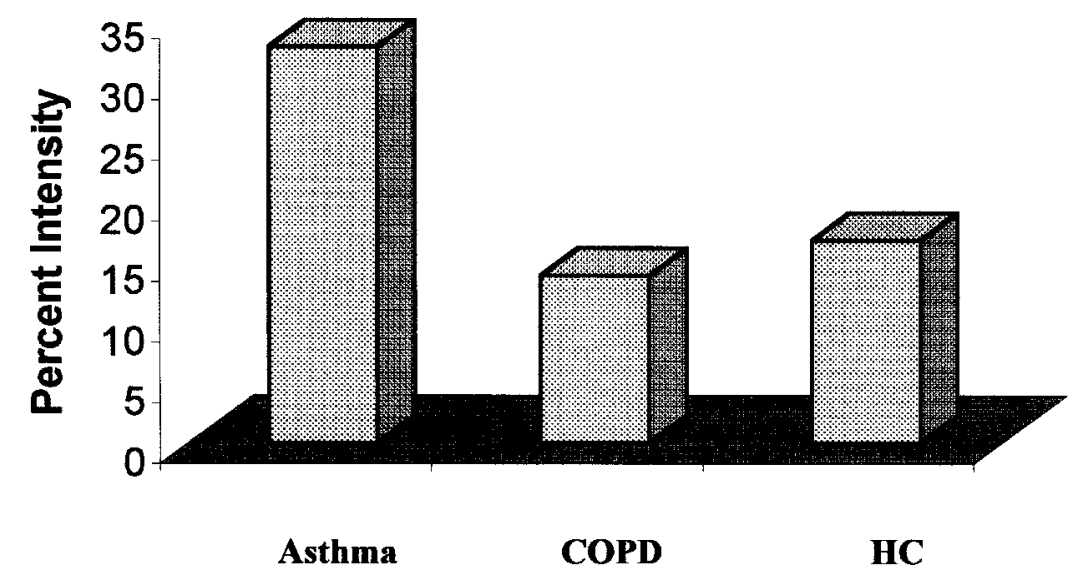

FIG. 2. Expression of $\mathrm{Bcl}-2$ in induced sputum mononuclear cells from 10 patients with asthma, 12 patients with COPD, and 10 healthy controls (HC). Densitometric scanning of the Western blot quantifies the expression of Bcl-2.

Induced sputum lymphocytes were cultured in the presence of vario us anti-cytokine antibodies, anti-IL-2, anti-IL- 4 , anti-IL-1 0 , anti-IL-13, and anti-TNF- $\alpha$ (Fig. 1). Anti-IL-2 antibodies inhibited the apoptosis both in patients with asthma and patients with COPD by $45 \%$ and $7 \%$ respectively. Anti-IL-10 blocked apoptosis exclusively in patients with asthma by $70 \%$ Anti-TNF$\alpha$ antibody inhibited the apoptosis in both patients groups and healthy controls, suggesting that TNF- $\alpha$ acted as an inducer of apoptosis.

\section{Expression of $\mathrm{Bcl}-2$ in induced sputum mononuclear cells}

The analys is of $\mathrm{Bcl}-2$, which is the apoptosis inhibiting protein, was estimated by Western blotting. The results were highly reproducible. The concordance of the repeated experiments $\mathrm{w}$ as for $\mathrm{Bcl}-2$ measurement of $87 \%$.

The expression of $\mathrm{Bcl}-2$ was found to be increased in induced sputum lymphocytes for patients with asthma $(32.7 \% \pm 7.4 \%)$ compared to healthy controls $(16.8 \% \pm 6.2 \%)$ and patients with COPD $(13.9 \% \pm$ $2.8 \%)(p<0.01)$ (Fig. 2). The Bcl-2 level was not significantly different in patients with COPD, and healthy controls. The Bcl-2 levels were also detected by two-color flow cytometry analysis (anti-CD3 and anti-Bcl-2 monoclonal antibodies) and similar results were obtained. Cells with light scatter characteristics of lymphocytes were gated and analyzed using LYSYS II software from FACScan flow cytometer (Becton Dickinson) (data not shown). ${ }^{7}$

\section{Expression of fas in induced sputum mononuclear cells}

We analyzed 10 samples of induced sputum from patients with asthma, from patients with COPD $(n=12)$ and from healthy controls $(n=10)$ for Fas expression. The percentage of stained cells was estimated for each slide. The results were represented individually for each patient (Fig. 3). A significantly

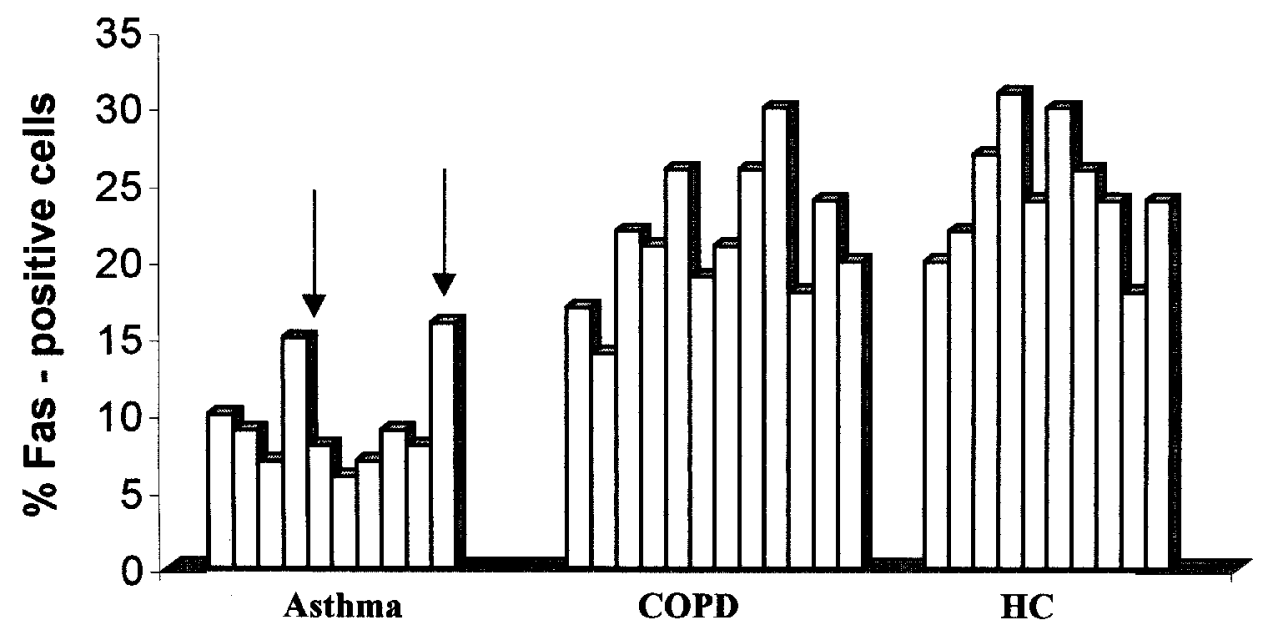

FIG. 3. Expression of Fas in induced sputum mononuclear cells from 10 patients with asthma, 12 patients with COPD, and 10 healthy controls $(\mathrm{HC})$. Individual values were expressed in percentage (number of Fas-positive cells/number of mononuclear cells $\times 100$ ). Asthmatic patients number 4 and $10[\rightarrow]$, have subnormal values of Fas-positive cells. According to Table 2 , they have low values of eosinophils. 
low expression of Fas could be detected in patients with asthma, when compared to COPD patients and to healthy controls $(p<0.01)$.

\section{Discussion}

Total cell count was elevated in patients with asthma and patients with COPD, compared to healthy controls. Sputum of patients with asthma and COPD expressed high percentages of eosinophils and lymphocytes. The lymphocytes were in the majority CD3positive (Tlymphocytes), and were activated $\left(\mathrm{CD} 25^{+}\right)$. The leukocytes count and phenotype of the lymphocytes showed that sputum traduced an inflammatory state in patients $w$ ith asthma and COPD. The results obtained from analyzing induced sputum in asthma and COPD patients reflect the inflammatory status of the bronchi.

The percentage of apoptosis was significantly decreased in patients with asthma compared with COPD patients and healthy controls. Anti-IL-2 antibodies inhibited the apoptosis both in patients with asthma and patients with COPD. Anti-IL-10 blocked apoptosis exclusively in patients with asthma. AntiTNF- $\alpha$ antibody inhibited the apoptosis in both patients groups and healthy controls, suggesting that TNF- $\alpha$ acted as an inducer of apoptosis.

The expression of $\mathrm{Bcl}-2$ was found to be increased in induced sputum lymphocytes from patients with asthma compared to healthy controls and patients with COPD.

A significantly low expression of Fas could be detected in patients with asthma, when compared to COPD patients and to healthy controls.

No correlation was found with asthma severity, or previous treatment. This can be linked to our protocol: all the samples were collected during an acute exacerbation requiring an admission. We can suppose that the severity of the acute process was similar within the patients and did not depend on the severity of the chronic disease. It would only depend on the pathology: asthma or COPD.

In an attempt to clarify if lymphocytes survival is modified in asthma, we investigated induced sputum samples. The percentage of apoptosis was significantly decreased in patients with asthma compared with COPD patients and healthy controls. The decreased apoptosis observed in patients may be associated with persistence of mononuclear cells in the bronchial mucosa and lumen, during the acute exacerbations. The low expression of apoptosis is more important in patients with asthma, when compared to COPD patients. This finding suggests a particular involvement of lymphocytes in acute asthma. Induction of apoptosis allowing the removal of the cells may be essential to resolve allergic inflammation, and the use of corticosteroids and theopylline in combination may be appropriate to induce apoptosis in eosinophils and lymphocytes. ${ }^{8}$

Interestingly, Vignola et al. $^{5}$ found significantly more apoptotic cells in the biopsy specimens of patients with chronic bronchitis than in tissues from asthmatic patients. The authors reported $\mathrm{also}^{5}$ that there is an imbalance between the expression of $\mathrm{Bcl}-2$ and p53, which appears to be more important in asthma than in chronic bronchitis. They concluded that airw ay inflammation in asthma is associated $w$ ith an enhanced survival of different cell types caused by reduced apoptosis. Our findings corroborate their findings, but we focused on lymphocytes. The percentage of intensity of the proto-oncogene $\mathrm{Bcl}-2$ was increased more in patients with asthma when compared to COPD and to the healthy control group. The Fas proto-oncogene which is involved in the induction of apoptosis was significantly decreased in patients with asthma, when compared to COPD patients and to healthy controls. If the Fas is involved in the induction of apoptosis at the same level as p 53, our reports were in accordance with those of Vignola et al. ${ }^{5}$ The Bcl-2 was found to be increased in the tissues from as thmatic subjects compared with those of the control subjects, and the expression correlated with the severity of asthma. ${ }^{5}$ Although Bcl-2 can be associated with resident cells (mucous gland and smooth muscle), both protein and message were specifically found in T-cells of the inflammatory infiltrate in subjects with asth ma and chronic bronchitis. ${ }^{9}$ Upregulated Fas ligand may trigger the apoptotic death of Fas-bearing cells. This study reported the dow $n$ expression of Fas in lymphocytes in sputum of asthmatic patients. Functional Fas receptor expression on eosinophils varies among individuals with hypereosinophilia, and the survival cytokine. ${ }^{10,11} \mathrm{We}$ have found that certain specific anti-cytokines antibodies blocked apoptosis, in partic ular anti-TNF- $\alpha$ and anti-IL1 0 in patients with asthma. Anti-TNF- $\alpha$ inhibited apoptosis in two patients groups and healthy controls. The blocking of apoptosis with anti-TNF- $\alpha$ antibody indicated that TNF- $\alpha$ is involved in inducing cell death. ${ }^{12,13}$ This correlates well with the findings that serum levels of TNF- $\alpha$ increase with the severity of disease. ${ }^{14}$

Incubation of lymphocytes from asthmatic patients with anti-IL-10 antibody decreased apoptosis more significantly than in patients with COPD or healthy controls. This shows that IL-10 had a specific role in asthma. We have recently reported that IL-10 is able to increase in vitro expression of $\mathrm{Bcl}-2$ in peripheral blood lymphocytes and in inflammatory lymphocytes from broncho-aveolar lavage and cerebrospinal fluid. ${ }^{7}$ It has been reported that continuous culture of T-cells in the presence of IL-10 will inhibit T-cell apoptosis, because of, at least in part, the upregulation of Bcl-2. ${ }^{15}$ In patients with asthma, anti-IL-10 antibody abolished apoptosis in asthma. This may have a particular 
signific ance. Anti-IL-10 could have a diffe rent effect on sputum T-lymphocytes or the action of anti-IL-10 was different, as has been observed in vivo, or in vitro long-term culture (more than 48 hours). IL-10, a product ofT helper 2 lymphocytes, has been show n to be an important regulator of peptide and alloantigeninduced T-cell proliferation and IL-2 production. ${ }^{16}$ Human IL-1 0 exerts a dose-dependent inhibitory effect on human stimulated lymphocytes in vitro. ${ }^{16}$

Interleukin-2 is a major T-cell grow th factor, and anti-IL-2 antibody inhibit apoptosis. ${ }^{17}$ In the present report anti-IL-2 antibody inhibited apoptosis more in asthma and COPD than in healthy controls. This finding could be explained by the fact that Tlymphocytes in sputum of patients played an inflammatory role and were probably producing high levels of inflammatory mediators. The anti-cytokines data further substantiate that IL-2 and IL- 10 are critical factors during inflammatory process in the lung.

Apoptosis signals are further modulated by inhibitors or inducers of apoptosis including Bcl-2, p53, Fas-ligand. Further understanding of the interaction of these molecules in asthma and COPD may lead to more specific therapies for immunosuppression tailored to the genetic or environmentally induced, activation-induced apoptosis defect in patients with asthma.

\section{References}

1. Hargreave FE, Popov T, Dolovich J. Sputum measurements to assess airway inflammation in asthma. Allergy 1993; 48: 81-83.

2. Grootendorst DC, van den Bo Romeijn JJ, Vaselic-Charvat M, Duiverman EJ, Vrijlandt EJLE, Sterk PJ, Roldaan AC. European respiratory Journal 1999; 13: 647-653.
3. Fahy JV, Liu J, Wong H, Boushey HA. Cellular and biochemical analysis of induced sputum from asthmatic and healthy subjects. American Review Respiratory Disease 1993; 147: 1126-1131.

4. Mountz DJ, Xiao Su ZT, Wu J, Cheng J. The role of programmed cell death as an emerging new concept for the pathogenesis of autoimmune diseases. Clinical Immunology and Immunopathology 1996; 80: S2-S14.

5. Vignola AM, Chanez P, Chiappara G, Siena L, Merendino A, Reina C, Gagliardo R, Profita M, Bousquet J, Bonsignori G. Evaluation of apoptos is of eosinophils, macrophages, and T lymphocytes in mucosal biopsy specimens of patients with asthma and chronic bronchitis. Journal Allergy Clinical Im munology 1999; 103: 555-558.

6. Global Initiative for Asthma. Global strate gy for asthma management and prevention. Publ. 95-3569, 1-176. Washington, DC, National Heart, Lung and Blood Institute, National Institutes of Health, 1995.

7. Hamzaoui K, Hamzaoui A, Zakraoui L, Chabbou A. Expression of Bcl-2 in inflammatory sites from patients with active Behçet's disease. Mediators of Inflam mation 1999; 8: 101-106.

8. Ohta K, Yamashita N. Apoptosis of eosinophils and lymphocytes in allergic inflammation. Journal Allergy Clinical Im munology 1999; 104: $14-21$.

9. Brattoa DL, Fadok VA. Theirs but to do and die: eosinophil longevity in asthma. Journal Allergy Clinical Im munology 1999; 103: 563-565.

10. Matsumoto K, Schleimer RP, Saito H, Bochner BS. Induction of apoptos is in human eosinophils by anti-Fas antibody treatment in vitro. Blood 1995; 86: 1437-1443.

11. Hebestreit H, Yousefi S, Balatti I. Expression and function of the Fas receptor on human blood and tissue eosinophils. European Journal of Im m unology 1996; 26: 1775-1780.

12. Zheng L, Fisher G, Miller RE, Peschon J, Lynch DH, Lenardo MJ. Induction of apoptosis in mature T cells by tumor necrosis factor. Nature 1995 377: 348-351.

13. Osthoff KS. The Fas/APO-1 receptor and its deadly ligand. Trends Cell Biology 1994; 4: 421-426.

14. Barnes PF, Chatterjee D, Brennan PJ, Rea TH. Tumor necrosis factor production in patients with leprosy. Infection and Im munity 1992; 60: 1441-1446.

15. Cohen SBA, Crawley JB, Kahan MC, Feldman M, Foxwell BMJ. Interleukin-10 rescues T cells from apoptotic cell death: associated with an upregulation of Bcl-2. Im m unology 1997; 92: 1-5.

16. Row bottom AW, Lepper MW, Garland RJ, Corly EG, Oakhill A, Stew art CG. Interleukin-10 induced CD8 cell proliferation. Immunology 1999; 98: 80-89.

17. Taga K, Chretien J, Cherney B, Brown M, Tosato G. IL-10 inhibits apoptotic cell death in human T cells straveted of IL-2. International Im munology 1993; 5: 1599-65.

Received 4 October 1999; accepted 11 October 1999 


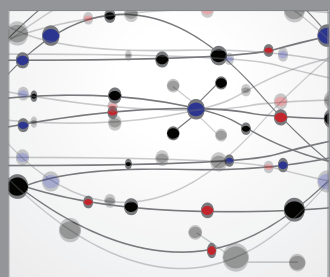

The Scientific World Journal
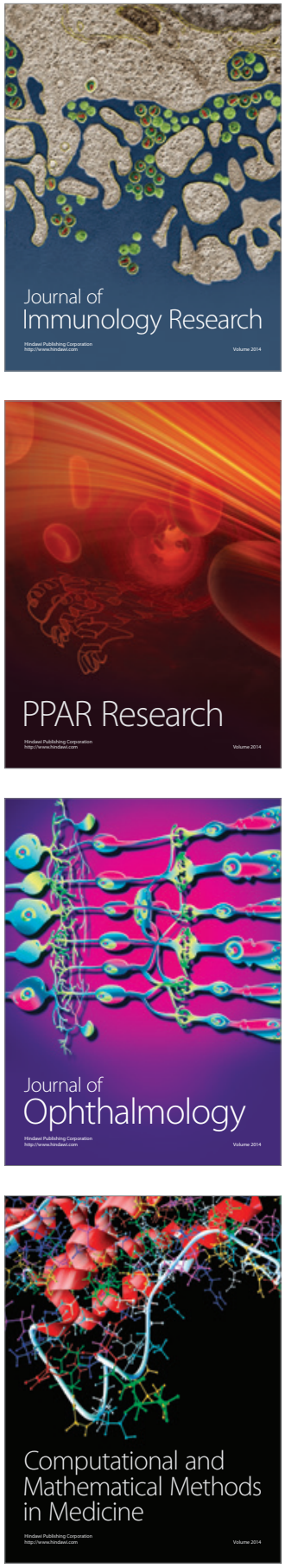

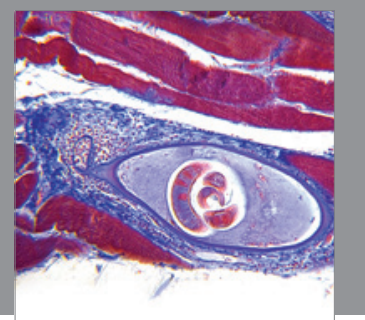

Gastroenterology

Research and Practice
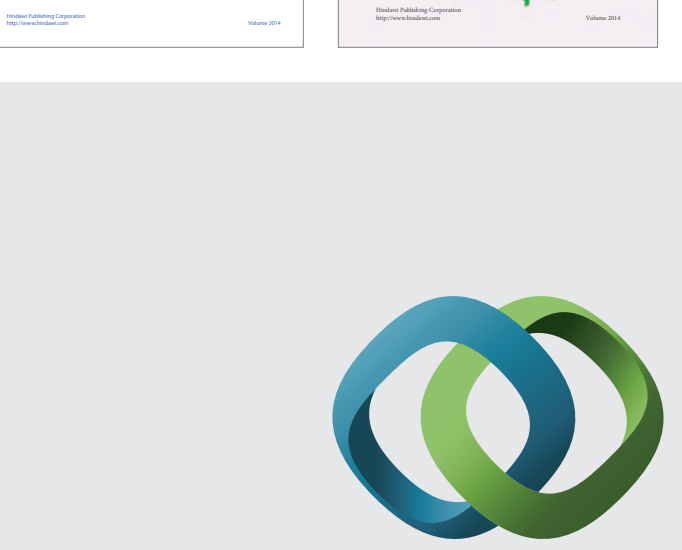

\section{Hindawi}

Submit your manuscripts at

http://www.hindawi.com
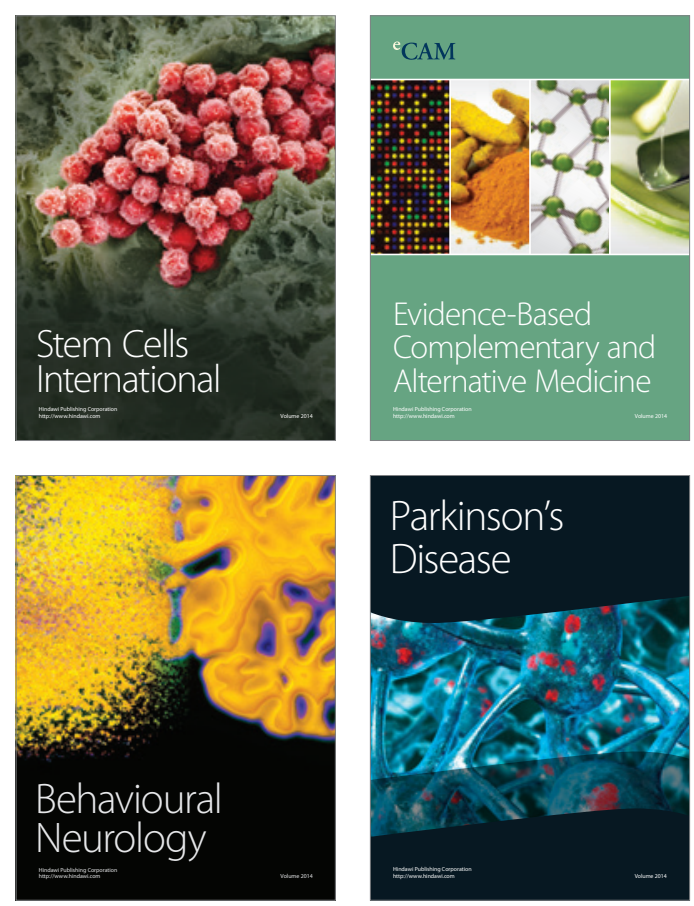

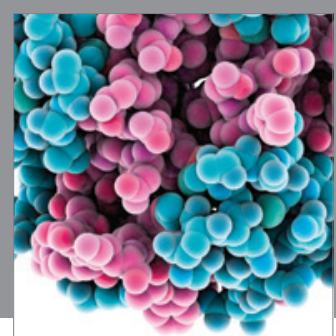

Journal of
Diabetes Research

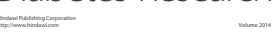

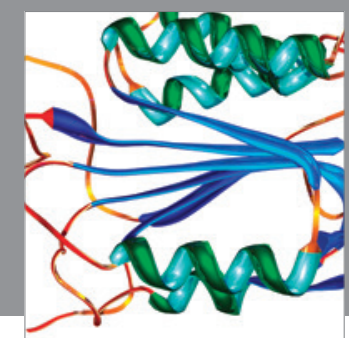

Disease Markers
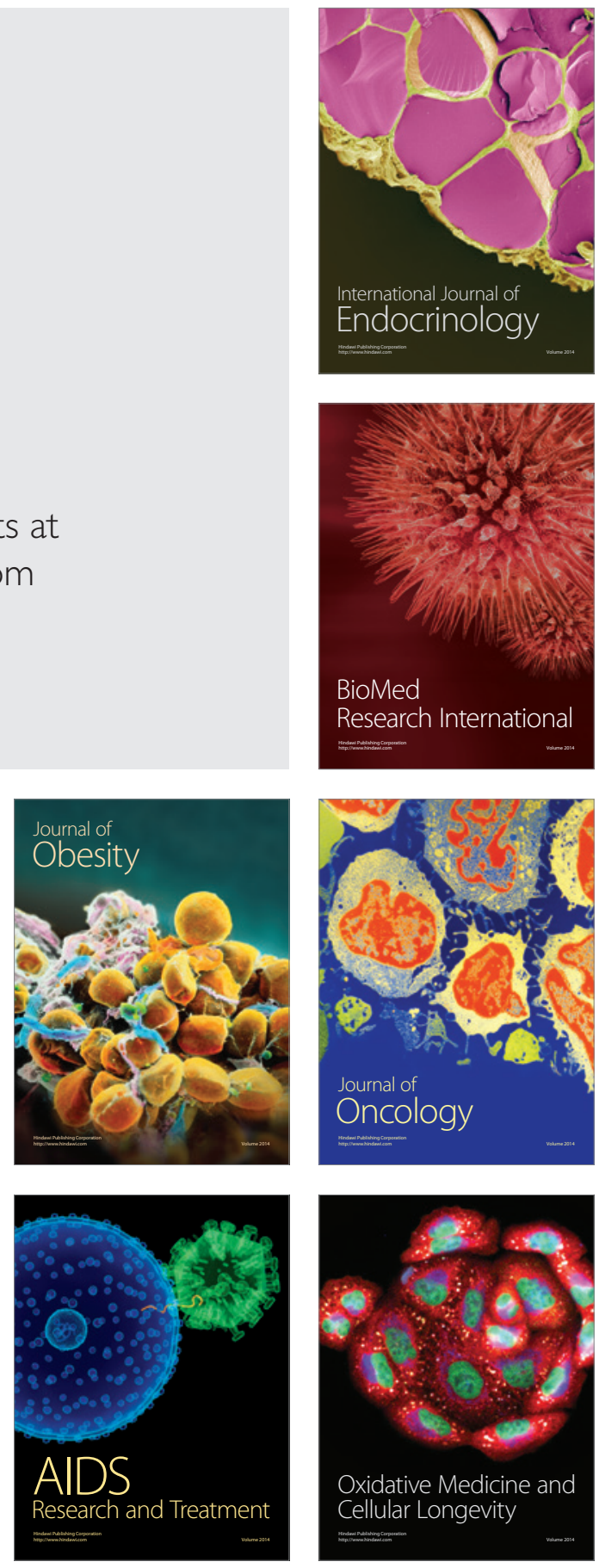